\title{
Isolated Renal Injury After Blunt Trauma: Case Report
}

\author{
Künt Travmaya Bağlı İole Böbrek Yaralanması: \\ Olgu Sunumu
}

\section{Havva Şahin Kavaklı, Orhan Delice}

Ankara Ataturk Research And Trainig Hospital, Emergency Department, Ankara

\begin{abstract}
The kidneys are rarely exposed to trauma by reason of localization. Renal trauma accounts for about 3\% of all trauma admissions and as many as $10 \%$ of patients who experience abdominal trauma. Our aim is to discuss a case with grade-5 kidney injury which was treated as conservative management. We report a case of isolated renal injury secondary to blunt abdominal trauma which was occured because of a bycyle accident. A 36-year-old male presented with left flank pain and gross hematuria after a bycycle accident with a direct trauma to his loin. After a diagnosis with computed tomography (CT) it was releaved that shattered kidney (grade-5 kidney injury). The patient hospitalized in urology department and has been treated with conservative management. At the end of the treatment he was discharged without any complication. It is considered that conservative management may be succesful in severe renal trauma.
\end{abstract}

Key words: Kidney injury, Trauma, Conservative management

\section{ÖZET}

Böbrekler lokalizasyonları nedeniyle nadiren travmaya maruz kalır. Renal travma tüm travma başvurularını \%3'ünü, abdominal travmaların ise $\% 10$ ’u oluşturur. Amacımız grade-5 böbrek yaralanması olup, konservatif tedavi edilen bir olguyu tartışmaktır. Bisiklet kazası nedeniyle görülen künt abdominal travmaya sekonder izole böbrek yaralanmasını rapor etmekteyiz. 36 yaşındaki erkek hasta bisiklet kazası sonrası bel bölgesine direkt travmayla gros hematüri ve sol flank ağrisıyla başvurdu. Hastaya bilgisayarlı tomografi ile grade- 5 böbrek yaralanması (paramparça böbrek) tanısı konuldu. Hasta üroloji servisinde yatırıldı ve konservatif yaklaşımla tedavi edildi. Herhangibir komplikasyon gelişmeyen hasta taburcu edildi. Bu olgu ciddi böbrek travmasında konservatif yaklaşımın başarılı olabileceğini düşündürmektedir.

Anahtar Kelimeler: Böbrek yaralanması, Travma, Konservatif yaklaşım

Iletişim Adresi ve Sorumlu Yazar:

Havva Şahin KAVAKLI

Ankara Atatürk Eğitim ve Araștırma Hastanesi Acil Servis, Bilkent 06800 Ankara-Türkiye

E-mail:hasan.kavakli@isbank.net.tr

Telefon: 05327840225 


\section{INTRODUCTION}

Renal trauma is a rare clinic entity. The mechanism of injury should alert the clinician to the possibility of renal trauma. Renal trauma results from different mechanisms including penetrating, blunt, iatrogenic, intraoperative and other causes. Management of renal trauma is always controversial. In general, conservative management is the preferred treatment in renal injury ${ }^{(1)}$. In this report we aimed to discuss importance of conservative management in kidney-5 injury.

\section{CASE}

A 36-year-old man presented to our emergency service with a serious left flank and inguinal area pain after blunt abdominal trauma sustained in a bicycle accident. The patient had no complaints previously also had no history of ilness. There was no a pre-existing renal lesion. In the physical examination conducted in the emergency service a mass was detected in left lower part of abdomen. Acute macroscopic hematuria were noted. Other system examination results were normal.

Body temperature was: $36.5^{\circ} \mathrm{C}$, number of breaths was: $22 /$ minute, blood pressure was: $130 / 80 \mathrm{mmHg}$, pulse: $78 / \mathrm{min}$. His hemoglobine level was $13.2 \mathrm{~g} / \mathrm{dL}$ and hematocrit level was $40.6 \%$. Kidney function levels were normal. Urinalysis showed abundant hematuria. Initially his hematocrit level decreased down to $32.2 \%$ and then it continued unchanged. There were no significant pathological findings in laboratuary analyses. Possibility of hematoma in left kidney was thought by use of ultrasonography. Abdominal CT revealed kidney laceration and major left renal hematoma (dimension $10 \mathrm{~cm}$ ) (Figure 1).

The patients lesion due to renal trauma was evaluated as grade-5 scale injury. The patient was hospitalised for observation in urology department. Hymodynamic parameters and vital signs were stable. It was preferred conservative management to the case. The patients kidney functions were in normal levels. Observation and non operative treatment was maintained in urology department. The patient was well and conservatively treated without any complications. He was discharged provided that he will come for check later.

\section{Figure.1}

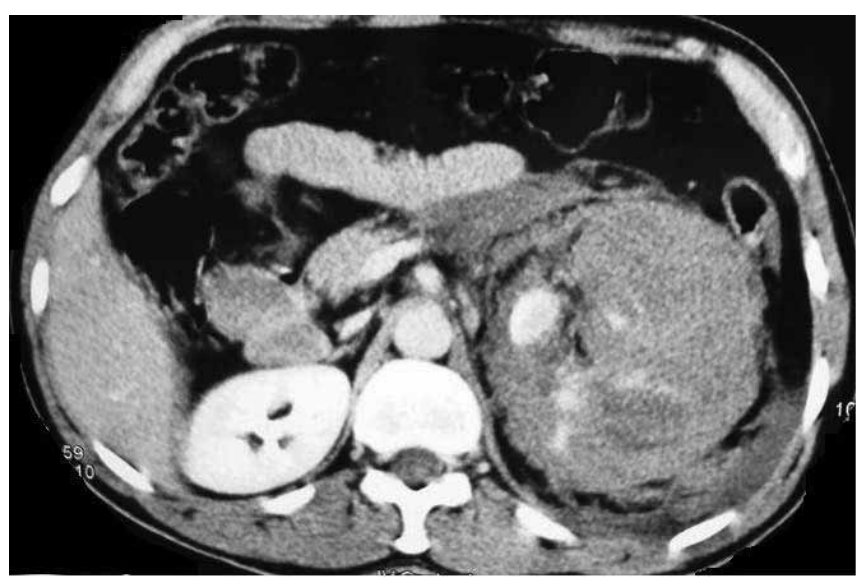

\section{DISCUSSION}

The main objective of this case report was to demonstrate that patients with kidney injuries, even grade-5 injury scale, could be treated adequately with conservative management. Renal trauma is classified into five grades with the majority of injuries being minor.Kidney injury diagnosis starts with a more suspicious approach depending on the mechanism of injury.Complaints of flank or abdominal pain after trauma should be assessed carefully. Urinalysis should be performed in patients who have renal trauma history. If gross hematuria is not present, a microscopic examination is advisable. In trauma patients hematuria generally indicates urinary tract damage, but renal injury cases with no hematuria have been reported. Other diagnostic tools include ultrasonography, intravenous pyelogram, angiography and CT. CT has become the standard diagnostic tool and should be applied in blunt trauma with macroscopic hematuria. The current management of blunt trauma of the kidney is based on the 5-grade classification of lesions described by the ASST (American Society of the Surgery of Trauma). Recent study verified that the AAST injury severity scale is very useful for prediction of clinical outcome in patients with renal trauma ${ }^{(2)}$.

Most blunt renal injuries are low-grade; therefore, they are usually amenable to treatment with observation and bed rest alone. Absolute indications for surgical revision are persistent life-threatening bleeding, renal pedicle injuries as well as an expanding, pulsatile retroperitoneal hematoma. Indications become relative in the presence of large devitalized renal tissue with urinary extravasation and other abdominal injuries, particularly of the pancreas and the colon. Surgical revision is more often indicated in open trauma, but surgery should enable renal reconstruction in the majority of cases ${ }^{(3)}$ Patients with indications for emergent exploration include those with hemodynamic instability. Expanding hematomas or active hemorrhage suggests the possibility of high-grade renal injury. All kidney trauma patients, should be monitored closely to ensure successful hemostasis. Serial hematocrit measurements should be considered.

Conservative management and aggressive intervention both have their proponents, but conservative treatment is generally favored nowadays, even in the case of grade $4 / 5$ trauma ${ }^{(4,5,6)}$. Conservative approach is adequate for major renal trauma as long as the patient is haemodynamically stable ${ }^{(6,7)}$. Urinary diversion by nephrostomy tube or ureteral stenting is not mandatory in most cases because the extravasation resolves in up to $90 \%$ of cases $^{(8)}$.

Overall, injury severity, severity of renal injury grade, hemodynamic instability, and transfusion requirements are predictive of nephrectomy after both blunt and penetrating trauma. Nephrectomy is more likely after penetrating injury ${ }^{(9)}$. In our case although severity of renal injury grade is high (grade V, shattered kidney), hemodynamic instability was not seen in observation period. Thus nephrectomy was not required.

In conclusion, initial nonsurgical management of high grade blunt renal trauma is effective and is recommended for the 
hemodynamically stable patient. Early operative management is rarely indicated for an isolated renal injury, except in the patient who is hemodynamically unstable. Our case was treated successfully without surgery. It demonstrates that in select cases grade-5 renal injuries can be managed conservatively. Especially in patients with left flank and inguinal area pain after blunt abdominal trauma, emergency physicians should be alert for kidney injury.

\section{REFERENCES}

1- Raheem O, St John Floyd M, Casey RG, Cullen IM, Corcoran MO, Bredin HC, et al. Renal trauma in the west of Ireland-a regional review. ScientificWorldJournal. 2009;9:137-43.

2- Shariat SF, Roehrborn CG, Karakiewicz PI, Dhami G, Stage KH. Evidence-based validation of the predictive value of the American Association for the Surgery of Trauma kidney injury scale. J Trauma. 2007 ;62:933-9.

3- Schmidlin F. Renal trauma. Treatment strategies and indications for surgical exploration. Urologe A. 2005 ;44:863-9.

4- Saidi A, Descotes JL, Sengel C, Terrier N, Manel A, Moalic R, et al. Management of blunt trauma of the kidney. Prog Urol. 2004 ;14:461-71.

5- Tsujimoto Y, Fujita M, Hatano K, Arai Y, Takada T, Takada $\mathrm{S}$ et al. Renal transection conservatively treated three times by selectively transarterial embolization (TAE): a case report. Hinyokika Kiyo. 2008 54:407-10.

6- Delgado Oliva FJ, Bonillo García MA, Gómez Pérez L, Oliver Amorós F, Gimeno Argente V, Jiménez Cruz JF. Conservative approach in major renal trauma. Actas Urol Esp. 2007 ;31:132-9.

7- Matsuura T, Nose K, Tahara H, Hara Y, Amasaki N, Nishioka $T$, et al. Evaluation of the management of blunt renal trauma and indication for surgery. Nippon Hinyokika Gakkai Zasshi. 2002 ;93:511-8.

8- Pfitzenmaier J, Buse S, HaferkampA, Pahernik S, Djakovic N, Hohenfellner M. Kidney injuries. Unfallchirurg. 2009 ;112:317-25.

9- Davis KA, Reed RL 2nd, Santaniello J, Abodeely A, Esposito TJ, Poulakidas SJ, et al. Predictors of the need for nephrectomy after renal trauma. J Trauma. 2006 ;60:164-9. 